\title{
Richtlijnen en privaatrecht
}

\author{
Mr.drs. D.F.H. Stein*
}

\section{Inleiding}

In een bijzonder nummer over 'gamechangers' in het Europees privaatrecht mag een bijdrage over richtlijnen van Unierecht niet ontbreken. ${ }^{1}$ Het is een open deur dat richtlijnen van belang zijn voor het privaatrecht, en eveneens dat richtlijnen voornamelijk invloed uitoefenen doordat zij in het nationale recht worden geïmplementeerd. In deze bijdrage illustreer ik het belang van richtlijnen voor het privaatrecht aan de hand van verschillende andere wijzen waarop richtlijnen het nationale en Europese (Unie)privaatrecht beïnloeden. Aan de hand daarvan bespreek ik in hoeverre richtlijnen voor het nationale én Unierechtelijke privaatrecht als 'gamechanger(s)' moeten worden aangemerkt. Het doel van dit artikel is niet om nieuwe aspecten van de invloed van richtlijnen op het privaatrecht te onderzoeken. Dit artikel biedt veeleer een overzicht van de verschillende wijzen waarop rechtssubjecten bescherming kunnen ontlenen aan niet, niet-juist en/of nietvolledig geimplementeerde (bepalingen uit) richtlijnen van Unierecht. Ik beperk mij daarbij tot het verbintenissenrecht.

Deze bijdrage is als volgt opgebouwd. $\mathrm{Na}$ een korte schets van de (door)werking van richtlijnen (par. 2), ga ik eerst in op het belang van richtlijnen voor het Nederlandse privaatrecht (par. 3). De nadruk in deze bijdrage zal liggen op het belang van richtlijnen voor de ontwikkeling van het Unie(privaat)recht (par. 4). Ik volsta niet met een schets van de huidige stand van zaken, maar werp ook een blik in de (nabije) toekomst: wat kunnen wij de komende jaren aan ontwikkelingen verwachten op dit gebied (par. 5)? Ik sluit af met enkele afrondende opmerkingen (par. 6).

\section{2 (Door)werking van richtlijnen}

Anders dan een verordening, die 'verbindend [is] in al haar onderdelen en rechtstreeks toepasselijk [is] in elke lidstaat' (art. 288 lid 2 VWEU), is een richtlijn gericht tot de lidstaten en is zij voor haar effect in beginsel afhankelijk van omzetting in het nationale recht. Het Unierecht laat het daarbij aan de lidstaten om de geschikte 'vorm en middelen' te kiezen voor het door de richtlijn beoogde resultaat (art. 288 lid 3

Mr. drs. D.F.H. Stein is promovendus en docent Burgerlijk recht aan de Radboud Universiteit Nijmegen en verbonden aan het Onderzoekcentrum Onderneming \& Recht (OO\&R). Hij is tevens redacteur van dit blad.

De auteur dankt Irene Aronstein voor haar opmerkingen bij een eerdere versie van dit artikel.

1. Onder 'Unierecht' versta ik het (positieve) recht van de Europese Unie. Europese rechtsvergelijkende projecten blijven buiten beschouwing Ook rechtsregels uit de EVRM-rechtsorde blijven als zodanig buiten beschouwing, behalve voor zover zij relevant zijn voor het Unierecht.
VWEU). ${ }^{2}$ Het is dan ook aan de lidstaten om de normen uit richtlijnen in te passen in het nationale recht.

Om deze reden komt aan richtlijnen in beginsel geen 'directe werking' toe. Directe of rechtstreekse werking houdt in dat een regel van Unierecht zonder tussenkomst van het nationale recht rechten of verplichtingen in het leven roept. ${ }^{3}$ Daarbij wordt onderscheid gemaakt tussen werking van richtlijnen in horizontale verhoudingen (dat wil zeggen: tussen particulieren onderling) en verticale verhoudingen (tussen een overheidsorgaan en een of meer particulieren). Het is vaste rechtspraak van het Hof van Justitie dat aan richtlijnen géén 'directe horizontale werking' toekomt, dat wil zeggen: particulieren kunnen aan richtlijnen geen rechten ontlenen die zij jegens andere particulieren kunnen inroepen. ${ }^{4}$ Illustratief is de zaak Faccini Dori, waarin ging het om Richtlijn 85/577/EG (inzake buiten verkoopruimten gesloten overeenkomsten ('colportage')). Mevrouw Faccini Dori - een consument - had op afstand een overeenkomst gesloten met Interdiffusion. Richtlijn 85/577/ EG bevatte het recht voor de consument om hiervan afstand doen. ${ }^{5}$ Toen zij van die mogelijkheid gebruik makte, bleef de afstand echter zonder gevolg. Italië had echter nagelaten de richtlijn om te zetten in Italiaans recht, en vanwege het ontbreken van directe horizontale werking kon zij een dergelijk recht ook niet rechtstreeks aan de richtlijn ontlenen. ${ }^{6}$ De verkoper kon haar dus gewoon aanspreken tot betaling van de koopprijs. ${ }^{7}$ In de zaak Pfeiffer ging het om Richtlijn 93/104/ EG (de arbeidstijdenrichtlijn). Deze richtlijn voorzag in een maximale wekelijkse arbeidstijd van 48 uur, terwijl het Duitse recht een langere arbeidstijd toestond. De heer Pfeiffer was werkzaam voor het Duitse Rode Kruis en zijn wekelijkse werktijd overschreed deze 48 uur. Het Hof van Justitie achtte de Duitse wettelijke regeling dan ook in strijd met de richtlijn. ${ }^{8}$

2. Zie over implementatie van richtlijnen uitgebreid A. Prechal, Directives in EC Law, Oxford: Oxford University Press 2005 (Prechal 2005), p. 73 e.v.

3. Asser/Hartkamp 3-I 2019/9.

4. HvJ EG 26 februari 1986, C-152/84, ECLI:EU:C:1986:84, Jur. 1986, p. 723 (Marshall I), r.o. 48-51; HvJ EG 14 juli 1994, C-91/92, ECLI:EU:C:1994:292, Jur. 1994, p. I-3325 e.v.; NJ 1995/321 (Faccini Dori), r.o. 20-25; HvJ EU 5 oktober 2004, gevoegde zaken C-397/01 t/ m C-403/01, ECLI:EU:C:2004:584, Jur. 2004, p. I-08835; NJ 2005/333, m.nt. M.R. Mok (Pfeiffer), r.o. 108-109; HvJ EU 24 januari 2012, C-282/10, ECLI:EU:C:2012:33, NJ 2012/154, m.nt. M.R. Mok (Dominguez), r.o. 42. Zie Asser/Hartkamp 3-I 2019/156 e.v.

5. Zie art. 5 lid 1 Richtlijn $85 / 577 /$ EG.

6. Faccini Dori (C-91/92), r.o. 19-25.

7. Wel oordeelde het Hof van Justitie dat Faccini Dori de daardoor geleden schade mogelijk kan verhalen op de Italiaanse staat, zie Faccini Dori (C-91/92), r.o. 27-30.

8. Pfeiffer (gevoegde zaken C-397/01 t/m C-403/01), r.o. 100. 
Aangezien de richtlijn niet in het Duitse recht was omgezet, kon Pfeiffer aan de richtlijn echter geen rechten ontlenen die hij tegen zijn werkgever kon inroepen. ${ }^{9}$ Naast het ontbreken van directe werking in horizontale verhoudingen, is het uitgangspunt dat richtlijnbepalingen ook in verticale verhoudingen niet zonder meer kunnen worden ingeroepen: richtlijnen hebben in beginsel ook geen 'directe verticale werking. ${ }^{10}$

Uitgangspunt is dus dat rechtssubjecten voor de werking van richtlijnen zijn aangewezen op implementatie in het nationale recht. ${ }^{11} \mathrm{Wel}$ zijn in het Unierecht verschillende remedies aanvaard voor het ontbreken van directe (verticale of horizontale) werking van richtlijnbepalingen, zoals de verplichting tot richtlijnconforme interpretatie en lidstaataansprakelijkheid. Voordat ik deze remedies bespreek (par. 4.2 en 4.3), ga ik eerst in op het belang van richtlijnen voor het Nederlandse privaatrecht.

\section{Richtlijnen en Nederlands privaatrecht}

\subsection{Implementatie van (normen uit) Unierechtelijke richtlijnen}

Als gevolg van de implementatie van richtlijnen in het Nederlandse privaatrecht zijn op verschillende plekken in het Burgerlijk Wetboek bepalingen terug te vinden die een Unierechtelijke oorsprong hebben. ${ }^{12}$ Dergelijke bepalingen kunnen niet los worden gezien van hun Unierechtelijke origine; zij moeten in overeenstemming met het Unierecht worden geïnterpreteerd. ${ }^{13}$ Daarbij moet de nationale rechter niet alleen de desbetreffende richtlijn(en) in acht nemen, maar het gehele Unierecht. ${ }^{14}$ Doorgaans roept een richtlijn slechts een minimaal niveau van bescherming in het leven ('minimumharmonisatie'), maar steeds vaker - zoals bij de Richtlijn consumentenrechten - stelt het een bovengrens aan het bescher-

9. Pfeiffer (gevoegde zaken C-397/01 t/m C-403/01), r.o. 107-109.

10. Asser/Hartkamp 3-I 2019/155.

11. Het Hof van Justitie heeft in twee zaken wél directe horizontale werking aangenomen van (specifieke) normen uit richtlijnen. Zie HvJ EG 30 april 1996, C-194/94, ECLI:EU:C:1996:172, Jur. 1996, p. I-02201; NJ 1997/214 (CIA Security) en HvJ EG 26 september 2000, C-443/98, ECLI:EU:C:2000:496, Jur. 2000, p. I-07535; NJ 2001/136 (Unilever Italia). Gelet op het incidentele karakter van deze wijze van doorwerking, wordt wel gesproken van 'incidentele directe horizontale werking', zie bijv. M. Dougan, When Worlds Collide! Competing Visions of the Relationship between Direct Effect and Supremacy, CMLR 2007, p. 931.

12. Te wijzen valt op onder meer afdeling 3.1A BW (elektronisch vermogensrechtelijk rechtsverkeer), art. 3:86a en 310a BW (cultuurgoederen), afdeling 6.3.3 BW (productaansprakelijkheid), afdeling 6.3.3A BW (oneerlijke handelspraktijken), afdeling 6.3.4A BW (aansprakelijkheid bij elektronisch rechtsverkeer), art. 6.5.2a BW (inzake dienstverlening), afdeling 6.5.2b BW (consumentenovereenkomsten), afdeling 6.5.3 BW (algemene voorwaarden), Titel 7.1 BW (consumentenkoop) Titel 7.2 BW (financiëlezekerheidsovereenkomsten) en afdeling 7.2A BW (consumentenkredietovereenkomsten).

13. Zie hierover nader par. 4.2.

14. M.H. Wissink, Interpretation of private law in conformity with EU directives, in: A.S. Hartkamp e.a. (red.), The Influence of EU Law on National Private Law, Deventer: Kluwer 2014 (Serie Onderneming en Recht, deel 81-I) (Wissink 2014), p. 120-121. Zie art. 4 lid 3 VWEU. mingsniveau ('maximumharmonisatie'). ${ }^{15}$ Het Unierecht belet dan dat lidstaten verdergaande maatregelen nemen. ${ }^{16}$

Van het Unierecht, in het bijzonder van consumentenbeschermende richtlijnen, gaat een harmoniserende werking uit. De doorwerking van richtlijnen in het nationale privaatrecht leidt tot een grotere convergentie van het nationale recht van de lidstaten. ${ }^{17}$ Niet altijd kiest de Nederlandse wetgever er bij implementatie voor om de inhoud van richtlijnbepalingen met zoveel woorden neer te leggen in nieuwe of bestaande wetsbepalingen. Zo koos de Nederlandse wetgever er aanvankelijk voor om de contra proferentem-regel uit Richtlijn 93/13/ EG (oneerlijke bedingen) niet volledig om te zetten in Nederlands recht. Deze regel schrijft voor dat schriftelijke bedingen in consumentenovereenkomsten steeds duidelijk en begrijpelijk moeten zijn opgesteld, en dat bij twijfel over de betekenis van een beding de voor de consument meest gunstige interpretatie prevaleert. ${ }^{18}$ Volgens de Nederlandse wetgever kon via art. 3:35 BW en art. 6:238 BW (zoals dat toen luidde) reeds worden bereikt dat een consument bescherming toekomt bij een beding dat niet voldoende duidelijk of begrijpelijk is. ${ }^{19} \mathrm{Na}$ een Europese inbreukprocedure is de Nederlandse wetgever alsnog overstag gegaan en is aan art. 6:238 BW een tweede lid toegevoegd. Ook in het kader van Richtlijn 2014/104/EU (schadevergoeding wegens schending van mededingingsrecht) heeft de Nederlandse wetgever niet alle normen uit de richtlijn overgenomen. Deze richtlijn bepaalt onder meer dat gezamenlijke inbreukplegers op het mededingingsrecht hoofdelijk aansprakelijk zijn voor de door die inbreuk veroorzaakte schade (art. 11 lid 1) en dat een hoofdelijk schuldenaar die tot betaling wordt aangesproken, verhaal kan nemen op de andere schuldenaren. De omvang van de bijdrageplicht van de schuldenaren wordt bepaald 'op basis van hun relatieve verantwoordelijkheid voor de door de inbreuk op het mededingingsrecht veroorzaakte schade' (art. 11 lid 5). De Nederlandse wetgever heeft deze frase niet overgenomen in afdeling 6.3.3A BW, omdat het door de richtlijn beoogde resultaat volgens hem reeds kan worden bereikt via art. 6:102 jo. art. 6:101 en 6:10 lid $2 \mathrm{BW} .{ }^{20}$ Mede gelet op de verplichting van de nationale rechter om deze regels richtlijnconform te interpreteren (zie hierna, par. 4.2), is het de vraag wat deze wijze van implementatie betekent voor de invulling van de in deze bepalingen vervatte normen in andere gevallen van hoofdelijke aansprakelijkheid, waarin het Unierecht géén rol speelt.

15. Zie daarover V. Mak, De grenzen van maximumharmonisatie in het Europese consumentenrecht, NTBR 2011/77, afl. 10, p. 558-564.

16. Asser/Hartkamp 3-I 2019/177.

17. Zie P-C. Müller-Graff, EU Directives as a Means of Private Law Unification, in: A.S. Hartkamp e.a. (red.), Towards a European Civil Code, Nijmegen/Alphen aan den Rijn: Ars Aequi Libri/Kluwer Law International 2011, p. 149-183.

18. Zie art. 5 Richtlijn 93/13/EG.

19. Kamerstukken II 1998/99, 26470, 3, p. 2. Zie hierover C.M.D.S. Pavillon, De invloed van Europese richtlijnen op de Nederlandse regeling van algemene voorwaarden (afdeling 6.5.3 BW), in: A.S. Hartkamp e.a. (red.), De invloed van het Europese recht op het Nederlandse privaatrecht, Deventer: Kluwer 2014, p. 233-265, nr. 15-16.

20. Kamerstukken II 2015/16, 34490, 3, p. 15-16. 


\section{Maandblad}

\subsection{Ambtshalve toetsing}

De implementatie van Unierecht heeft doorgaans vooral betrekking op de harmonisatie van materieelrechtelijke en niet zozeer procesrechtelijke normen. Dit laat onverlet dat het Unierecht voor de effectuering van normen met een Unierechtelijke oorsprong afhankelijk is van de verschillende nationale rechtsgangen in de lidstaten. Bij gebreke van een Unierechtelijke rechtsgang is het overgelaten aan het nationale recht van de lidstaten om de procedure vorm te geven waarin consumenten Unierechtelijke rechten kunnen effectueren (het beginsel van 'procedurele autonomie'). ${ }^{21}$ Het gaat daarbij niet alleen om regels die naar Nederlands recht als procesrecht worden aangemerkt (zoals het Wetboek van Burgerlijke Rechtsvordering), maar ook om regels inzake aansprakelijkheid en verjaring, die wij naar nationaal recht als materieelrechtelijk zouden aanmerken. Deze autonomie van de lidstaten wordt onder andere begrensd door de beginselen van gelijkwaardigheid en doeltreffendheid (de 'Rewe/Comet-doctrine'). ${ }^{22}$ Kort gezegd komt het gelijkwaardigheidsbeginsel erop neer dat het nationale procesrecht schendingen van Unierecht niet ongunstiger mag behandelen dan soortgelijke nationale vorderingen; het doeltreffendheidsbeginsel houdt in dat het nationale procesrecht de effectuering van door het Unierecht toegekende rechten en plichten niet uiterst moeilijk of praktisch onmogelijk mag maken. ${ }^{23}$

De procedurele autonomie wordt daarnaast begrensd in gevallen waarin het Unierecht zelf wél procedureregels formuleert. In sommige richtlijnen is daarvan sprake, ${ }^{24}$ maar dat

21. Zie over de verhouding met nationaal recht met name W. van Gerven, Of Rights, Remedies and Procedures, CMLR 2000, p. 501-536, en N. Reich, Horizontal liability in EC law: Hybridization of remedies for compensation in case of breaches of EC rights, CMLR 2000, p. 705-742. Zie ook M. Bobek, Why There is No Principle of 'Procedural Autonomy' in the Member States, in: B. de Witte \& H-W. Micklitz (red.), The European Court of Justice and Autonomy of the Member States, Antwerpen: Intersentia 2011, p. 305-322 (Bobek 2011).

22. HvJ EG 16 december 1976, C-33/76, ECLI:EU:C:1976:188, Jur. 1976 , p. 1989 e.v. (Rewe), r.o. 5; HvJ EG 16 december 1976, C-45/76, ECLI:EU:C:1976:191, Jur. 1976, p. 2043 e.v. (Comet), r.o. 13. Zie onder meer J.M. Prinssen, Doorwerking van Europees recht. De verhouding tussen directe werking, conforme interpretatie en overheidsaansprakelijkheid (diss. Amsterdam UvA), Deventer: Kluwer 2004 (Serie Europese Monografieën, deel 73), p. 33-36; H.B. Krans, Nederlands burgerlijk procesrecht en materieel EU-recht, Deventer: Kluwer 2010 (Serie Burgerlijk Proces \& Praktijk, deel 12), p. 5-7; W. Devroe \& P. Van Cleynenbreugel, The Impact of General Principles of EU Law on Private Law Relationships, in: A.S. Hartkamp e.a. (red.), The Influence of EU Law on National Private Law, Deventer: Kluwer 2014 (Serie Onderneming en Recht, deel 81-I), nr. 24; R. Meijer, The Rewe/Comet 'doctrine' and its implications for Dutch law, in: Serie Onderneming en Recht, deel 81-I (2014), p. 39 e.v.; Asser Procesrecht/Giesen 1 2015/92-93; en C. Heinze, Schadensersatz im Unionsprivatrecht (Habilitationsschrift Hamburg), Tübingen: Mohr Siebeck 2017, p. 8-9. Er is ook kritiek op dit leerstuk, zie Bobek 2011 en A-M. Van den Bossche, Private Enforcement, Procedural Autonomy and Article 19(1) TEU: Two's Company, Three's a Crowd, Yearbook of European Law 2014/1, p. 41-83.

23. Beide beginselen kunnen worden gezien als een uitwerking van het Unierechtelijke effectiviteitsbeginsel, zie Asser/Hartkamp 3-I 2019/111.

24. Zie bijvoorbeeld Richtlijn 2014/104/EU, art. 5 t/m 9 . geldt niet voor alle richtlijnen. Daarnaast heeft het Hof van Justitie de ruimte genomen om in zijn rechtspraak procesrechtelijke normen te formuleren. Dat is met name het geval bij de handhaving van rechten die zijn neergelegd in consumentenbeschermende richtlijnen. In verschillende arresten heeft het Hof van Justitie geoordeeld dat uit het Unierecht de verplichting voor de rechter kan voortvloeien om een overeenkomst (of beding) ambtshalve te toetsen aan Unierechtelijke normen. Nadat het Hof van Justitie al een verplichting tot ambtshalve toetsing in het leven had geroepen voor de mededingingsrechtelijke verbodsbepalingen van art. 101 en 102 VWEU, ${ }^{25}$ heeft het een vergelijkbare verplichting aanvaard voor normen die zijn vervat in verschillende consumentenbeschermende richtlijnen, te weten Richtlijn 93/13/EG (oneerlijke bedingen), ${ }^{26}$ Richtlijn 2008/48/EG (consumentenkrediet), ${ }^{27}$ Richtlijn 85/577/EG (buiten verkoopruimten gesloten overeenkomsten ('colportage')), ${ }^{28}$ en Richtlijn 1999/44/EG (consumentenkoop). ${ }^{29}$ Aangezien aan richtlijnen geen directe horizontale werking toekomt, gaat het hierbij niet om toetsing van bedingen aan de desbetreffende richtlijnen zélf, maar om toetsing aan het toepasselijke nationale recht waarin die richtlijnen (zouden moeten) zijn geïmplementeerd. ${ }^{30}$ Doordat het Hof van Justitie hier oordeelt dat de nationale rechter verplicht is tot ambtshalve

25. Zie HvJ EG 1 juni 1999, C-126/97, ECLI:EU:C:1999:269, Jur. 1999, p. I-03055; NJ 2000/339, m.nt. H.J. Snijders onder NJ 2000/340 (Eco Swiss), r.o. 36-41; HvJ EU 13 juli 2006, gevoegde zaken C-295/04 t/m 298/04, ECLI:EU:C:2006:461, Jur. 2006, p. I-06619; NJ 2007/34, m.nt. M.R. Mok (Manfredi), r.o. 31; HvJ EU 4 juni 2009, C-8/08, ECLI:EU:C:2009:343, Jur. 2009, p. I-04529; NJ 2009/432, m.nt. M.R. Mok (T-Mobile), r.o. 49. Vgl. echter nog HvJ EG 14 december 1995, gevoegde zaken C-430/93 en C-431/93, ECLI:EU:C:1995:441, Jur. 1995, p. I-04705; NJ 1997/116, m.nt. H.J. Snijders onder NJ 1997/118 (Van Schijndel).

26. HvJ EG 27 juni 2000, gevoegde zaken C-240 t/m C-244/98, ECLI:EU:C:2000:346, Jur. 2000, p. I-04941; NJ 2000/730 (Océano), r.o. 26; HvJ EU 26 oktober 2006, C-168/05, ECLI:EU:C:2006:675, Jur. 2006, p. I-10421; NJ 2007/201, m.nt. M.R. Mok (Mostaza Claro), r.o. 36-39; HvJ EU 4 juni 2009, C-243/08, ECLI:EU:C:2009:350, Jur. 2009, p. I-04713; NJ 2009/395, m.nt. M.R. Mok (Pannon), r.o. 32; HvJ EU 6 oktober 2009, C-40/08, ECLI:EU:C:2009:615, Jur. 2009, p. I-09579; NJ 2010/11, m.nt. M.R. Mok (Asturcom), r.o. 52-59; HvJ EU 9 november 2010, C-137/08, ECLI:EU:C:2010:659, Jur. 2010, p. I-10847; NJ 2011/41, m.nt. M.R. Mok (Pénzügyi), r.o. 56; HvJ EU 14 juni 2012, C-618/10, ECLI:EU:C:2012:349, NJ 2012/512, m.nt. M.R. Mok (Banco Español de Crédito), r.o. 42; HvJ EU 30 mei 2013, C-488/11, ECLI:EU:C:2013:341, NJ 2013/487, m.nt. M.R. Mok (Asbeek Brusse), r.o. 44-46.

27. HvJ EU 4 oktober 2007, C-429/05, ECLI:EU:C:2007:575, Jur. 2007, p. I-08017; NJ 2008/37, m.nt. M.R. Mok (Rampion), r.o. 60-69.

28. HvJ EU 17 december 2009, C-227/08, ECLI:EU:C:2009:792, Jur. 2009, p. I-11939; NJ 2010/225, m.nt. M.R. Mok (Martín Martín), r.o. 29.

29. HvJ EU 3 oktober 2013, C-32/12, ECLI:EU:C:2013:637, n.g. (Duarte), r.o. 39 en 43; HvJ EU 4 juni 2015, C-497/13, ECLI:EU:C: 2015:357, NJ 2016/148 (Faber), r.o. 56.

30. Wel lijkt het soms alsof de nationale rechter een rechtsverhouding toetst aan het Unierecht, omdat hij toetst aan de nationale wetgeving, die hij richtlijnconform interpreteert. Vgl. HR 13 september 2013, ECLI:NL:HR:2013:691, NJ 2014/274, m.nt. H.B. Krans; JOR 2013/329 (Heesakkers/Voets), r.o. 3.7.1. 
toetsing, ${ }^{31}$ beperkt het Unierecht de procedurele autonomie van het nationale recht op dit punt. ${ }^{32}$

Veruit het meest ontwikkeld is de rechtspraak over de beoordeling van bedingen in overeenkomsten als al dan niet oneerlijk in de zin van (de implementatiewetgeving ten aanzien van) Richtlijn 93/13/EG. In grofweg de afgelopen twee decennia heeft het Hof van Justitie de piketpalen geslagen voor de verplichting van de nationale rechter om de geldigheid van bedingen uit consumentenovereenkomsten zo nodig ambtshalve te onderzoeken. Waar het Hof van Justitie in het arrest Océano nog sprak van een 'bevoegdheid' tot ambtshalve toetsing, ${ }^{33}$ is inmiddels duidelijk dat het gaat om een verplichting. ${ }^{34} \mathrm{De}$ nationale rechter is verplicht om een beding uit een voorliggende overeenkomst te beoordelen op het al dan niet oneerlijke karakter daarvan, mits de rechter beschikt over 'de daartoe noodzakelijke gegevens, feitelijk en rechtens' ${ }^{35}$ Hieraan gaat de vraag vooraf of een beding valt onder de werkingssfeer van de Richtlijn oneerlijke bedingen. In het arrest Pénzügyi oordeelde het Hof van Justitie dat de rechter verplicht kan zijn om 'ambtshalve maatregelen van instructie te nemen' om te onderzoeken of dat het geval is. ${ }^{36} \mathrm{Zo}$ ja, dan dient hij het beding inhoudelijk te beoordelen, zo nodig ambtshalve. Uit het Unierecht vloeit dus een toetsing in twee fasen voort: ${ }^{37}$ in de eerste fase onderzoekt de rechter of het beding valt onder de werkingssfeer van de Richtlijn oneerlijke bedingen en is hij verplicht om zo nodig ambtshalve instructiemaatregelen te treffen, in de tweede fase is hij weliswaar verplicht om ambtshalve te onderzoeken of het beding oneerlijk is, maar alleen indien hij beschikt over de daartoe noodzakelijke gegevens

31. Ik gebruik de term 'ambtshalve toetsing' om duidelijk te maken dat het gaat om de beoordeling door de rechter van de geldigheid van een beding, zonder dat de partijen in de procedure daarop met hun stellingen zelf aansturen.

32. Dit is niet de plaats om in te gaan op de uitvoerige discussie in de literatuur over de verschillende grondslagen voor ambtshalve toepassing van Unierecht. Zie voor een overzicht van de verschillende argumenten met name A.S. Hartkamp, Ambtshalve aanvulling van rechtsgronden naar Europees recht en naar Nederlands recht (oratie Nijmegen), Deventer: Kluwer 2007; A.G.F. Ancery, Ambtshalve toepassing van EU-recht (diss. Groningen), Deventer: Kluwer 2012 (Serie Burgerlijk Proces en Praktijk, deel XIV); H.J. Snijders, New Developments in National Rules for ex Officio Raising of Points of Community Law by National Courts, in: A.S. Hartkamp e.a. (red.), The Influence of EU Law on National Private Law, Deventer: Kluwer 2014, p. 95-118; en Van Leuken 2018.

33. Océano (gevoegde zaken C-240 t/m C-244/98), r.o. 26.

34. Mostaza Claro (C-168/05), r.o. 36-39; Pannon (C-243/08), r.o. 32. Zie hierover R.W.E. van Leuken, Ambtshalve toepassing van EU-recht: stand van zaken en toekomstige ontwikkelingen, in: C.J.H. Jansen, M.M.C. van de Moosdijk \& R.W.E. van Leuken (red.), Nijmeegs Europees privaatrecht (Liber amicorum Prof. mr. drs. C.H. Sieburgh), Deventer: Wolters Kluwer 2018 (Van Leuken 2018), p. 135.

35. Pannon (C-243/08), r.o. 32.

36. Pénzügyi (C-137/08), r.o. 56.

37. Zie HR 13 september 2013, ECLI:NL:HR:2013:691, NJ 2014/274, m.nt. H.B. Krans (Heesakkers/Voets), r.o. 3.5 e.v., voor de inbedding van deze regels in het nationale burgerlijke procesrecht. In HR 26 februari 2016, ECLI:NL:HR:2016:340, NJ 2017/214, m.nt. H.B. Krans; JBPr 2016/36, m.nt. D.F.H. Stein (Stichting Trudo), r.o. 3.4, heeft de Hoge Raad verduidelijkt hoe in hoger beroep met deze verplichting moet worden omgegaan. Zie voorts Ancery 2012/301; Van Leuken 2018, p. 136-137. (feitelijk en rechtens). Deze verplichtingen vloeien rechtstreeks uit het Unierecht voort en bestaan dus ongeacht of de rechter een dergelijke bevoegdheid aan het nationale recht kan ontlenen. ${ }^{38}$

De uit (de volle werking van) het Unierecht voortvloeiende verplichting om zo nodig ambtshalve te onderzoeken of een overeenkomst of beding in overeenstemming is met normen die afkomstig zijn uit consumentenbeschermende richtlijnen, gaat verder dan waartoe het Nederlandse procesrecht verplicht. De Nederlandse rechter is naar Nederlands procesrecht immers weliswaar bevoegd om onder omstandigheden instructiemaatregelen te treffen, maar is daartoe in algemene zin niet verplicht (vgl. art. $22 \mathrm{Rv}$ ). Op grond van het Unierecht is hij dat wel: zowel op grond van de hiervoor aangehaalde rechtspraak, als op grond van het arrest Asturcom, waaruit volgt dat indien een nationale rechter bevoegd is ambtshalve onderzoek te verrichten, hij daartoe in het kader van de toepassing van consumentenbeschermende richtlijnen verplicht is. ${ }^{39}$

\subsection{Reflexwerking}

De invloed van het Unierecht reikt soms verder dan waartoe het Unierecht verplicht. Geregeld is sprake van een zekere 'reflexwerking'. Daarmee doel ik op gevallen waarin het Unierecht op zich niet verplicht om een regel van Unierecht toe te passen, maar waarin dat in het Nederlandse recht toch gebeurt.

Het bekendste voorbeeld hiervan betreft ongetwijfeld de reflexwerking van art. 6:236-238 BW inzake algemene voorwaarden. ${ }^{40}$ Deze bepalingen bevatten onder meer de 'zwarte lijst' en 'grijze lijst', waarop bedingen in overeenkomsten staan vermeld die geacht of vermoed worden onredelijk bezwarend te zijn (art. 6:236 en 237 BW). Komt vast te staan dat een beding een onredelijk bezwarend karakter heeft, dan is het beding vernietigbaar (art. 6:233 aanhef en sub a BW). Art. 6:236-238 BW zijn slechts van toepassing op algemene voorwaarden die jegens consumenten worden ingeroepen, ${ }^{41}$ waarbij geldt dat als gevolg van de richtlijn oneerlijke bedingen en de daarbij behorende lijst van indicatieve en niet uitputtende oneerlijke bedingen nog enige wijzigingen zijn aangebracht. ${ }^{42}$ Hoewel de zwarte en grijze lijsten slechts door consumenten kunnen worden ingeroepen, is het niet uitgesloten dat hiervan ook invloed uitgaat op dergelijke

38. Zie voor de vraag in hoeverre het arrest Pénzügyi voor het Nederlandse recht verandering meebrengt Ancery 2012/303-315.

39. Asturcom (C-40/08), r.o. 52-59. Het gaat dan om ambtshalve toetsing die wordt 'aangewakkerd' door het Unierechtelijke gelijkwaardigheidsbeginsel. Zie ook Asbeek Brusse (C-488/11), r.o. 44-46.

40. Ook kan worden gewezen op de reflexwerking van de regels inzake consumentenkoop. Zie daarover M.B.M. Loos, Consumentenkoop (Mon. BW nr. B65b), Deventer: Wolters Kluwer 2019, nr. 13.

41. De bepalingen spreken van 'een wederpartij, natuurlijk persoon, die niet handelt in de uitoefening van een beroep of bedrijf.

42. Richtlijn 93/13/EEG van de Raad van 5 april 1993 betreffende oneerlijke bedingen in consumentenovereenkomsten (PbEG 1993, L 95/29), art. 3 lid 1, art. 5 en Bijlage. 
bedingen in niet-consumentenovereenkomsten. ${ }^{43}$ Zo worden met enige regelmaat bedingen in overeenkomsten die zijn gesloten met niet-consumenten - rechtspersonen of natuurlijke personen die wél handelen in de uitoefeningen van een beroep of bedrijf - getoetst aan art. 6:236 of 237 BW. Dat kan door analoge toepassing van deze bepalingen, ${ }^{44}$ maar ook door invulling van de open norm van art. 6:233 BW. ${ }^{45}$ Omdat in de grijze en zwarte lijsten inmiddels ook bedingen zijn opgenomen met een Unierechtelijke herkomst, is dan sprake van reflexwerking van het Unierecht.

Een andere vorm van reflexwerking is zichtbaar bij de hiervoor besproken verplichting om de geldigheid van bedingen uit consumentenovereenkomsten ambtshalve te toetsen. De Hoge Raad heeft de Unierechtelijke verplichting tot ambtshalve toetsing doorgetrokken naar de regels inzake koop op afbetaling, die van nationale origine zijn. ${ }^{46}$ In het arrest Lindorff/ Statia oordeelde de Hoge Raad dat een 'all-in' mobiele telefonie-abonnement - dat wil zeggen: een abonnement waarbij voor één maandelijks bedrag zowel telecommunicatiediensten worden geleverd als een mobiele telefoon in eigendom wordt overgedragen - onder omstandigheden kwalificeert als consumentenkrediet in de zin van Richtlijn 2008/48/EG (zie art. 7:61 e.v. BW). ${ }^{47}$ De gedachte is dat de maandelijkse abonnementssom niet alleen betrekking heeft op de telecommunicatiediensten, maar ook voor een deel 'aflossing' is van de waarde van het toestel. Aangezien de consument het toestel reeds in eigendom heeft verkregen, maar daarvoor nog niet de volledige koopprijs heeft betaald, is hem een krediet verleend ter grootte van (het restant van) de verschuldigde koopprijs. ${ }^{48}$ De consument kan de overeenkomst in zoverre (partieel) vernietigen. ${ }^{49}$ Gelet op de Unierechtelijke achtergrond van art. 7:61 e.v. BW dient de rechter dient zo nodig ambtshalve te onderzoeken of aan de wettelijke vereisten is voldaan, zo blijkt uit het arrest Lindorff/Nazier. ${ }^{50}$ In ditzelfde arrest oordeelde de Hoge Raad dat hier niet alleen sprake is van consumentenkrediet, maar (doorgaans) ook van koop op afbetaling, omdat er sprake is van koop waarbij de koopprijs in meerdere termijnen wordt

43. C.H. Sieburgh, Mr. C. Assers Handleiding tot de beoefening van het Nederlands Burgerlijk Recht. 6. Verbintenissenrecht. Deel III. Algemeen overeenkomstenrecht, Deventer: Wolters Kluwer 2018, nr. 502.

44. Zie bijv. Hof Arnhem-Leeuwarden 28 maart 2017, ECLI:NL:GHARL: 2017:2679, r.o. 5.5 .

45. Zie bijv. Hof 's-Hertogenbosch 19 maart 2019, ECLI:NL:GHSHE: 2019:1034 (NVLF/Itec), r.o. 6.6.3-6.6.4.

46. Het ging om art. 7A:1576 e.v. (oud) BW. Vgl. thans art. 7:84 e.v. BW.

47. HR 13 juni 2014, ECLI:NL:HR:2014:1385, NJ 2015/477, m.nt. J. Hijma; JOR 2014/206, m.nt. J.M. van Poelgeest \& J.W.A. Biemans (Lindorff/Statia), r.o. 3.5.3.

48. Waarbij het, gelet op de vaste abonnementssom, uiteraard de vraag is hoe men vaststelt wat die koopprijs nu is; partijen waren nu immers juist geen losse koopprijs overeengekomen.

49. Lindorff/Statia, r.o. 3.6.

50. HR 12 februari 2016, ECLI:NL:HR:2016:236, NJ 2017/282, m.nt. J. Hijma; JOR 2016/127, m.nt. J.W.A. Biemans \& J.M. van Poelgeest (Lindorff/Nazier), r.o. 3.8.1.

51. Zie art. 7A:1576 e.v. (oud) BW. Vgl. thans art. 7:84 e.v. BW. betaald. ${ }^{51} \mathrm{Er}$ is in de regel dus sprake van samenloop. ${ }^{52}$ Anders dan art. 7:61 e.v. BW, zijn deze bepalingen niet van Unierechtelijke origine. Desalniettemin heeft de Hoge Raad ook voor dergelijke bepalingen de verplichting tot ambtshalve toetsing aanvaard omdat er op dit punt volgens de Hoge Raad 'geen relevant verschil' bestaat. ${ }^{53}$ De verplichting om naast aan de regels inzake consumentenkrediet óók ambtshalve te toetsen aan de regels inzake koop op afbetaling, gaan verder dan waartoe het Unierecht verplicht. Het effect van deze verplichting doet zich uiteraard het sterkst gelden in verstekzaken. ${ }^{54}$

Ten slotte kan nog worden gewezen op het Eigen Haardarrest. In dit arrest oordeelde de Hoge Raad dat bij een beroep op ontbinding - het ging hier om een huurovereenkomst ten aanzien van sociale woonruimte - in beginsel aan de tekortschietende partij is om te stellen en zo nodig te bewijzen dat de tekortkoming de ontbinding niet rechtvaardigt. ${ }^{55}$ Daarbij geldt echter een lage stelplicht voor de tekortschietende partij en dient de rechter óók in verstekzaken te toetsen of de ontbinding de tekortkoming rechtvaardigt. ${ }^{56}$ Hoewel de Hoge Raad hier niet spreekt van ambtshalve toetsing, is daarvan in ieder geval in verstekzaken wel degelijk sprake. ${ }^{57} \mathrm{Ik}$ zou hier niet willen spreken van reflexwerking van Unierecht, maar ik sluit niet uit dat de Hoge Raad hierbij met een schuin oog heeft gekeken naar de Unierechtelijke verplichting om zo nodig ambtshalve te toetsen aan consumentenbeschermende bepalingen van Unierecht. ${ }^{58}$

\section{Het belang van richtlijnen voor het Unierecht}

\subsection{Inleiding}

Ook voor het Unierecht zélf zijn richtlijnen van groot belang. $\mathrm{Zij}$ dragen - in ieder geval op het gebied van het consumentenrecht - bij aan het ontstaan van een Europees 'acquis communautaire'. Sommigen hebben zelfs gedacht aan een Europees burgerlijk wetboek, al dan niet beperkt tot het consumentenrecht. ${ }^{59}$ De werking van richtlijnen heeft ook tot gevolg gehad dat in het Unierecht verschillende remedies zijn aanvaard voor de gevallen waarin richtlijnen na het verstrijken van de implementatietermijn niet, niet-juist of niet-volledig in nationaal recht zijn omgezet. ${ }^{60}$ Zoals ik in de volgende para-

52. Zie voor kritiek op deze gedachte N. Huppes, C.M.D.S. Pavillon \& T.L. Wildenbeest, De fabel van het gratis mobieltje, NTBR 2019/5, afl. 2, p. 20-32.

53. Lindorff/Nazier, r.o. 3.11.1-3.11.2.

54. Vgl. Lindorff/Nazier, r.o. 3.9 en 3.11.1.

55. HR 28 september 2018, ECLI:NL:HR:2018:1810, n.n.g. (Eigen Haard), r.o. 3.6.

56. Eigen Haard, r.o. 3.7 en 3.9.

57. Er wordt dan immers getoetst - beoordeeld - of de ontbindingsverklaring effect heeft, gelet op het bepaalde in art. 6:265 lid $1 \mathrm{BW}$.

58. Vgl. J.J. Dammingh, De ontbinding van een overeenkomst, ORP 2019/33, afl. 2, p. 20.

59. Zie M.W. Hesselink, Naar een (Europees) wetboek van consumentenrecht?, NJB 2007/293, en de verschillende bijdragen in A.S. Hartkamp e.a. (red.), Towards a European Civil Code, Nijmegen/Alphen aan den Rijn: Ars Aequi Libri/Kluwer Law International 2011.

60. F.G. Jacobs, The Evolution of the European Legal Order, CMLR 2004, p. 307. 
grafen zal toelichten, heeft juist het ontbreken van directe werking van richtlijnen sterk aan deze ontwikkeling bijgedragen.

\subsection{Remedies in horizontale rechtsverhoudingen}

\section{Algemeen}

Het ontbreken van directe horizontale werking brengt mee dat in een geschil tussen particulieren geen beroep kan worden gedaan op een niet-geïmplementeerde richtlijnbepaling. In die verhouding laat zich ook niet betogen dat een nationale wettelijke regeling met zo'n richtlijn in strijd is (geen rechtmatigheidstoetsing aan richtlijnen in een geschil tussen particulieren). ${ }^{61}$ Voor andere direct (verticaal of horizontaal) werkende normen van Unierecht bestaat die mogelijkheid wel: gelet op de voorrang van Unierecht is de nationale rechter verplicht om nationale wetgeving die in strijd is met een norm van Unierecht, buiten toepassing te laten. ${ }^{62}$ Het ontbreken van directe horizontale werking van een richtlijnbepaling staat er echter niet aan in de weg dat een richtlijn op andere, indirecte wijzen van invloed kan zijn op een rechtsverhouding tussen particulieren ('indirecte horizontale werking').

\section{Richtlijnconforme interpretatie}

Het ontbreken van de mogelijkheid om nationale wetgeving aan een niet-geïmplementeerde richtlijn(bepaling) te toetsen belet niet dat nationale rechters het nationale recht richtlijnconform interpreteren. ${ }^{63}$ In verschillende arresten heeft het Hof van Justitie geoordeeld dat de uitleg van nationale rechtsnormen weliswaar is voorbehouden aan de nationale rechter, maar dat de nationale rechter - als orgaan van een lidstaat wel verplicht is het nationale recht dat verband houdt met het Unierecht richtlijnconform te interpreteren. ${ }^{64}$ Deze verplichting vloeit voort uit de werking van richtlijnen (thans art. 288 lid 3 VWEU) en het beginsel van Unietrouw (art. 4 lid 3

61. HvJ EG 13 november 1990, C-106/89, ECLI:EU:C:1990:395, Jur. 1990, p. I-04135 (Marleasing), r.o. 6; Pfeiffer (gevoegde zaken C-397/01 t/m C-403/01), r.o. 109; HvJ EU 19 januari 2010, C-555/07, ECLI:EU:C:2010:21, Jur. 2010, p. I-00365; NJ 2010/256, m.nt. M.R. Mok (Kücükdeveci), r.o. 46; Dominguez (C-282/10), r.o. 42; HvJ EU 15 januari 2014, C-176/12, ECLI:EU:C:2014:2, NJ 2014/246, m.nt. M.R. Mok (Association de médiation sociale $(A M S))$, r.o. 36; HvJ EU 7 augustus 2018, C-122/17, ECLI:EU:C:2018:631, n.n.g. (Smith), r.o. 42-44; HvJ EU 6 november 2018, gevoegde zaken C-569/16 en 570/16, ECLI:EU:C:2018:871, n.n.g. (Bauer en Broßonn), r.o. 76-78; en HvJ EU 22 januari 2019, C-193/17, ECLI:EU:C:2019:43, n.n.g. (Cresco), r.o. $72-73$.

62. HvJ EG 9 maart 1978, C-106/77, ECLI:EU:C:1978:49, Jur. 1978, p. 629 e.v.; NJ 1978/656 (Simmenthal), r.o. 17.

63. Zie hierover uitgebreid M.H. Wissink, Richtlijnconforme interpretatie van burgerlijk recht (diss. Leiden), Deventer: Kluwer 2001 (Wissink 2001) en Wissink 2014.

64. HvJ EG 10 april 1984, C-14/83, ECLI:EU:C:1984:153, Jur. 1984, p. 01891 (Von Colson en Kamann), r.o. 26.

65. Prechal 2005, p. 180-181; Asser/Hartkamp 3-I 2019/181.
VWEU); ${ }^{65}$ zij is 'inherent aan het systeem van het Verdrag. ${ }^{66}$ Geregeld gaat het Hof van Justitie in op deze mogelijkheid nadat het heeft vastgesteld dat de aan de orde zijnde richtlijn geen directe (horizontale) werking heeft. ${ }^{67}$ Zo kon de vennootschap Marleasing jegens een andere Spaanse vennootschap geen rechtstreeks beroep doen op Richtlijn 61/151/ EEG (inzake aandeelhoudersrechten), maar diende de Spaanse rechter het nationale recht wel in overeenstemming met deze richtlijn uit leggen. ${ }^{68}$ Ook liet het ontbreken van directe horizontale werking van Richtlijn 85/577/EEG (colportage) voor Faccini Dori onverlet dat de Italiaanse rechter het nationale rechter in overeenstemming met die richtlijn diende uit te leggen. ${ }^{69}$

Het karakter van de verplichting tot richtlijnconforme interpretatie als remedie voor niet, niet-juiste of niet-volledige implementatie brengt mee dat zij pas ontstaat indien de implementatietermijn is verstreken. ${ }^{70}$ Indien een richtlijn(bepaling) niet in het nationale recht is geïmplementeerd, kan het door de richtlijn beoogde resultaat dus soms alsnog worden bereikt door het nationale recht richtlijnconform te interpreteren.

\section{Toetsing van nationale wetgeving aan een grondrecht of algemeen beginsel van Unierecht waarvan de richtlijnbepaling een uitdrukking vormt (rechtmatigheidstoetsing)}

Een relatief recente ontwikkeling betreft de toetsing aan Unierechtelijke algemene beginselen waarvan een richtlijnbepaling een uitdrukking vormt, en die wél kunnen worden ingeroepen in een geschil tussen particulieren om nationale wetgeving aan te toetsen. ${ }^{71}$ In de arresten Mangold en Kücükdeveci heeft het Hof van Justitie aanvaard dat het ontbreken van directe horizontale werking van een richtlijnbepaling niet eraan in de weg staat dat in een geschil tussen particulieren wordt getoetst aan een algemeen beginsel van Unierecht waarvan de desbetreffende bepaling een uitdrukking vormt.

In beide gevallen ging het om de Richtlijn 2000/78/EG (inzake gelijke behandeling). ${ }^{72}$ In Mangold stond een nationale wettelijke regeling in de weg aan de effectuering van de rechten van de heer Mangold, omdat voor werknemers van ouder

66. Pfeiffer (gevoegde zaken C-397/01 t/m C-403/01), r.o. 114; Dominguez (C-282/10), r.o. 24-25. Het Hof van Justitie gebruikt voor de aansprakelijkheid van lidstaten eenzelfde formule, zie HvJ EG 19 november 1991, gevoegde zaken C-6/90 en C-9/90, ECLI:EU:C:1991:428, Jur. 1991, p. I-05357; NJ 1994/2 (Francovich), r.o. 35.

67. Wissink 2001, p. 215 e.v.

68. Marleasing (C-106/89), r.o. 6 en 7.

69. Faccini Dori (C-91/92), r.o. 26.

70. HvJ EU 4 juli 2006, C-212/04, ECLI:EU:C:2006:443, Jur. 2006, p. I-06057; NJ 2006/593, m.nt. M.R. Mok (Adeneler), r.o. 111-115. Zie reeds Prechal 2005, p. 191 e.v. Vóór dat moment geldt uiteraard wel reeds het beginsel van Unietrouw.

71. Zie hierover uitgebreid de bijdrage van Aronstein in dit nummer en voorts Asser/Hartkamp 3-I 2019/144 en T. Tridimas, The General Principles of EU Law, Oxford: Oxford University Press 2006.

72. Richtlijn $2000 / 78 / \mathrm{EG}$ van de Raad van 27 november 2000 tot instelling van een algemeen kader voor gelijke behandeling in arbeid en beroep (PbEG 2000, L 303/16). 
dan 60 jaar een ruimere mogelijkheid bestond om arbeidsovereenkomsten voor bepaalde tijd aan te gaan dan voor jongere werknemers het geval was. Dit was in strijd met de richtlijn, maar de desbetreffende wettelijke regeling kon de twee geschillen tussen particulieren niet aan de richtlijn worden getoetst. In Kücükdeveci ging het eveneens om arbeidsverhouding. Kücükdeveci was op haar achttiende in dienst getreden bij werkgever Swedex. Zij werkte daar tien jaar en werd vervolgens ontslagen. Kücükdeveci kwam op tegen dit ontslag, omdat Swedex volgens haar de opzeggingstermijn foutief had berekend. Swedex beriep zich echter op een Duitse wettelijke regeling op grond waarvan arbeidsjaren van vóórdat de werknemer de leeftijd van 25 jaren heeft bereikt, niet in acht worden genomen bij het bepalen van de opzeggingstermijn. Ook hier rees de vraag of deze regeling in strijd was met Richtlijn 2000/78/EG, maar kon de nationale wettelijke regeling niet aan de richtlijn worden getoetst. In Mangold aanvaardde het Hof van Justitie een algemeen Unierechtelijk beginsel van non-discriminatie wegens leeftijd, ${ }^{73}$ waaraan de nationale rechter - op grond van diens algemene verplichting om nationale wetgeving bij strijd met Unierecht buiten toepassing te laten ${ }^{74}$ - de nationale wettelijke bepaling wél kon toetsen. Daarbij overwoog het Hof dat de richtlijn niet de grondslag is van het beginsel van gelijke behandeling, maar daarvan juist de uitdrukking vormt. ${ }^{75}$ Dit algemene beginsel van Unierecht kan in een geschil tussen particulieren wél worden ingeroepen (om een nationale wettelijke regeling aan te toetsen, 'indirecte horizontale werking'). Daardoor ontleent een particulier aan dit beginsel de bescherming die hij aan de niet-geïmplementeerde richtlijn niet kan ontlenen. In de arresten $A M S$ en Dansk Industri heeft het Hof van Justitie deze lijn verder doorgezet en verhelderd. ${ }^{76}$ Voorwaarde voor toepassing van dit leerstuk is wel dat het door de richtlijn beoogde resultaat niet reeds kan worden bereikt door richtlijnconforme interpretatie. ${ }^{77}$

Het Hof van Justitie heeft voor verschillende grondrechten uit het Handvest van de Grondrechten van de Europese Unie ('EU-Handvest') eenzelfde werking aanvaard. ${ }^{78}$ Indien nationale wetgeving niet kan worden getoetst aan een non-discriminatiebepaling uit een richtlijn omdat die niet (voldoende) is

73. HvJ EU 22 november 2005, C-144/04, ECLI:EU:C:2005:709, Jur. 2005, p. I-09981; NJ 2006/227, m.nt. M.R. Mok (Mangold), r.o. 75.

74. Simmenthal (C-106/77), r.o. 20-21.

75. Mangold (C-144/04), r.o. 74-76; Kücükdeveci (C-555/07), r.o. 51 Daarmee kan de aanvaarde toetsingsmogelijkheid dogmatisch worden verklaard doordat algemene beginselen van Unierecht in de Unierechtelijke rechtsorde van hogere orde zijn dan richtlijnen, zodat het ontbreken van directe horizontale werking van een richtlijnbepaling er uiteraard niet aan kan afdoen dat het aan de orde zijnde beginsel ten volle wordt geëffectueerd, zie Asser/Hartkamp 3-I 2019/159.

76. Association de médiation sociale (AMS) (C-176/12), r.o. 47; HvJ EU 19 april 2016, C-441/14, ECLI:EU:C:2016:278, n.g. (Dansk Industri), r.o. 27.

77. Association de médiation sociale (AMS) (C-176/12), r.o. 23-40. Zie C.H Sieburgh, Waarom het Unierecht de invloed van grondrechten op het privaatrecht aanjaagt en versterkt, RM Themis 2015/1 (Sieburgh 2015), p. 9.

78. Zie hierover uitgebreid de bijdrage van Emaus aan dit nummer, par. 4. geïmplementeerd in het nationale recht, is soms niet alleen een algemeen beginsel in het geding, maar ook een grondrecht uit het EU-Handvest. Zo verbiedt art. 21 EU-Handvest discriminatie wegens godsdienst of levensovertuiging, terwijl dat ook verboden wordt door de hiervoor genoemde Richtlijn 2000/78/EG, inzake gelijke behandeling (en door het algemene Unierechtelijke non-discriminatiebeginsel). In de zaak Egenberger beantwoordde het Hof van Justitie de vraag of in een dergelijk geval een nationale wet die in een geschil tussen particulieren niet aan de richtlijn kan worden getoetst, wél kan worden getoetst aan art. 21 EU-Handvest. ${ }^{79}$ Het ging daar om een vacature voor een niet-religieuze functie bij een kerkgenootschap (namelijk een project tot het opstellen van een mensenrechtenrapport over rassendiscriminatie), waarbij in de vacature duidelijk werd gemaakt dat de sollicitant lid diende te zijn van een evangelische kerk of andere kring van christelijke kerken, en dat de sollicitant in zijn curriculum vitae diende te vermelden tot welke geloofsgemeenschap hij behoorde. Egenberger behoorde niet tot een geloofsgemeenschap en viel af in de tweede ronde van de sollicitatieprocedure. Uiteindelijk ging de baan naar iemand die wél had aangegeven tot een evangelische geloofsgemeenschap te behoren. In een door Egenberger tegen het kerkgenootschap aangespannen procedure legde de Duitse rechter aan het Hof van Justitie de vraag voor of hij de Duitse wetgeving op dit punt buiten toepassing moest laten, indien hij tot het oordeel zou komen dat zij in strijd was met de richtlijn. Het Hof van Justitie oordeelde allereerst dat het verbod van discriminatie op grond van godsdienst of levensovertuiging niet alleen is neergelegd in de richtlijn, maar ook een algemeen beginsel van Unierecht vormt en is opgenomen in art. 21 lid 1 EU-Handvest. ${ }^{80} \mathrm{Het}$ Hof oordeelde dat de nationale rechter verplicht is om - zo nodig - elke daarmee strijdige nationale bepaling buiten toepassing te laten, ook al is sprake van een geschil tussen particulieren. ${ }^{81}$ Eenzelfde oordeel gaf het Hof van Justitie korte tijd later in de zaak Broßonn, waarin het ging om toetsing van een nationale wettelijke bepaling aan art. 31 lid 2 EUHandvest. ${ }^{82}$ Hoewel toetsing van een nationale wettelijke bepaling aan de richtlijn in beide gevallen niet mogelijk was

79. HvJ EU 17 april 2018, C-414/16, ECLI:EU:C:2018:257, n.n.g. (Egenberger).

80. Egenberger (C-414/16), r.o. 76 .

81. Egenberger (C-414/16), r.o. 76-79. Het onderscheid tussen toetsing aan richtlijnen in verticale rechtsverhoudingen en in horizontale rechtsverhoudingen wordt in deze zaak overigens mooi zichtbaar, zie r.o. 74-78. De zaak Bauer betrof een verticale rechtsverhouding, waarin toetsing aan de richtlijn wél mogelijk was (rechtmatigheidstoetsing van nationale wetgeving aan direct verticaal werkende richtlijnbepaling). In de zaak Broßonn ging het om een horizontale rechtsverhouding, waar deze mogelijkheid ontbreekt.

82. Bauer en Broßonn (gevoegde zaken C-569/16 en 570/16), r.o. 86. Het ging hier om Richtlijn 2003/88/EG van het Europees Parlement en de Raad van 4 november 2003 betreffende een aantal aspecten van de organisatie van de arbeidstijd (PbEG 2003, L 299/9). 
omdat het ging om een geschil tussen particulieren, ${ }^{83}$ kon zij dus wel aan het EU-Handvest worden getoetst (indirecte horizontale werking). Daarvoor is wel vereist dat de desbetreffende norm volstaat om aan particulieren rechten te verlenen. ${ }^{84}$

\section{Directe horizontale werking van grondrechten uit het EU- Handvest}

Inmiddels is duidelijk dat het Hof van Justitie nog een stap verder gaat, en ook directe horizontale werking van verschillende EU-Handvestbepalingen aanvaardt. ${ }^{85}$ Deze koerswijziging is opvallend, omdat het Hof van Justitie in het arrest $A M S$ directe horizontale werking van art. 27 EU-Handvest (informatierecht werknemers) nog expliciet van de hand wees (omdat deze bepaling niet volstond om particulieren rechten te verlenen). ${ }^{86}$ Inmiddels heeft het Hof geoordeeld dat zowel art. 21 lid 1 als art. 31 lid 2 EU-Handvest 'op zich [volstaat] om aan particulieren een recht te verlenen dat deze als zodanig kunnen doen gelden in een geding tussen hen op een gebied dat onder het Unierecht valt' ${ }^{87}$ In het arrest Egenberger oordeelde het Hof in dit kader dat art. 21 EU-Handvest '[g]elet op zijn dwingende werking zich in beginsel niet [onderscheidt] van de verschillende bepalingen van de oprichtingsverdragen die diverse vormen van discriminatie verbieden, zelfs wanneer die discriminatie voortvloeit uit overeenkomsten tussen particulieren'. ${ }^{88}$ Daarmee is het niet alleen mogelijk om nationale wetgeving te toetsen aan de desbetreffende EU-Handvestbepalingen, maar kunnen particulieren ook rechtstreeks rechten ontlenen aan (sommige bepalingen uit) het EU-Handvest. ${ }^{89}$ Op deze wijze kan de norm die in een richtlijn is opgenomen, maar niet, niet-juist of niet-volledig is geïmplementeerd, dus alsnog worden geëffectueerd omdat zij ook in een andere Unierechtelijke rechtsbron is neergelegd (die wel als zodanig door particulieren kan worden ingeroepen). Juridisch gezien gaat het daarbij uiteraard dan

83. Het onderscheid tussen toetsing aan richtlijnen in verticale rechtsverhoudingen en in horizontale rechtsverhoudingen wordt mooi zichtbaar in Bauer en Broßonn (gevoegde zaken C-569/16 en 570/16), r.o. 74-78. De zaak Bauer betrof een verticale rechtsverhouding, waarin toetsing aan de richtlijn wél mogelijk was (rechtmatigheidstoetsing van nationale wetgeving aan direct verticaal werkende richtlijnbepaling). In de zaak Broßonn ging het om een horizontale rechtsverhouding, waar deze mogelijkheid ontbreekt.

84. Egenberger (C-414/16), r.o. 76 .

85. A.S. Hartkamp, Rechtstreekse doorwerking van het EU Handvest van de grondrechten in privaatrechtelijke rechtsverhoudingen, Ars Aequi 2019/3 (Hartkamp 2019), p. 223; M. de Mol, Het leerstuk van de horizontale directe werking van Unie grondrechten op de voet gevolgd, Ars Aequi 2019/5 (De Mol 2019), p. 377.

86. Association de médiation sociale (AMS) (C-176/12), r.o. 41-45 en 47. Zie hierover uitgebreid Sieburgh 2015, p. 8 e.v.

87. Zie ten aanzien van art. 21 lid 1 EU-Handvest: Egenberger (C-414/16), r.o. 76; Bauer en Broßonn (gevoegde zaken C-569/16 en 570/16), r.o. 89; Cresco (C-193/17), r.o. 76. Zie ten aanzien van art. 31 lid 2 EUHandvest: Bauer en Broßonn (gevoegde zaken C-569/16 en 570/16), r.o. 85 .

88. Egenberger (C-414/16), r.o. 77 .

89. Zo was de onderneming Cresco op grond van art. 31 lid 2 EU-Handvest verplicht om een vergoeding te betalen aan werknemers die op Goede Vrijdag geen extra toeslag betaald kregen omdat zij niet behoorden tot een evangelisch kerkgenootschap, zie Cresco (C-193/17), r.o. 89. niet meer om toepassing van de richtlijn, maar om toepassing van die andere Unierechtelijke rechtsbron.

\subsection{Remedies in verticale verhoudingen}

Ontbreken de hiervoor besproken mogelijkheden, omdat richtlijnconforme interpretatie niet mogelijk is en er géén algemeen beginsel of grondrecht van Unierecht in het geding is, dan kan de particulier zijn in een richtlijn vervatte rechten niet met succes jegens andere particulieren inroepen. $\mathrm{Hij}$ is dan aangewezen op remedies in verticale verhoudingen, dus jegens een overheid (of overheidsorgaan). Het Hof van Justitie heeft voor verticale rechtsverhoudingen een uitzondering aanvaard op het beginsel dat richtlijnen geen directe werking hebben (zie hiervoor, par. 2). Particulieren kunnen jegens een overheidsorgaan soms wél een beroep doen op een niet-omgezette richtlijnbepaling. ${ }^{90}$ Gaat het om een rechtsverhouding tussen particulieren, dan biedt deze remedie geen soelaas. Wel kan dan worden gedacht aan schadevergoeding van de staat die heeft nalaten de richtlijn tijdig en/of behoorlijk te implementeren. ${ }^{91}$ In het arrest Francovich heeft het Hof van Justitie een Unierechtelijke aansprakelijkheid van lidstaten in het leven geroepen voor schade als gevolg van schending van Unierecht. ${ }^{92}$ Het ging in deze zaak om het niet-implementeren van een richtlijn die strekte tot bescherming van werknemers tegen insolventie van hun werkgever. De Italiaanse staat had nagelaten om deze richtlijn om te zetten in nationaal recht, waardoor (onder meer) Francovich en Bonifaci schade leden toen hun werkgever failleerde. Zij stelden de Italiaanse staat daarvoor aansprakelijk. Nadat het Hof van Justitie eerst had overwogen dat in de gegeven omstandigheden geen rechtstreeks beroep kon worden gedaan op de richtlijn, ${ }^{93}$ aanvaardde het Hof van Justitie een 'beginsel dat de staat aansprakelijk is voor schade die particulieren lijden als gevolg van schendingen van het gemeenschapsrecht die hem kunnen worden toe-

90. Zie HvJ EG 4 december 1974, C-41/74, ECLI:EU:C:1974:133, Jur 1974, p. 1337 e.v. (Van Duyn), r.o. 12; HvJ EG 5 april 1979, C-148/78, ECLI:EU:C:1979:110, Jur. 1979, p. 1629 e.v. (Ratti), r.o. 21. Zie voor een overzicht van de verschillende argumenten voor directe verticale werking Prechal 2005, p. 218-240; S. Van Loock, I. Samoy \& J. Pisuliński, Directives, in: A.S. Hartkamp, C.H. Sieburgh \& W. Devroe (red.), Cases, Materials and Text on European Law and Private Law, Oxford/ Portland: Hart Publishing 2017, p. 351-352.

91. Zie het arrest Francovich (gevoegde zaken C-6/90 en C-9/90) en opvolgende rechtspraak. Zie voor een bespreking van lidstaataansprakelijkheid R. Meijer, Staatsaansprakelijkheid wegens schending van Europees gemeenschapsrecht (diss. Groningen), Deventer: Kluwer 2007. Zie over de verhouding tussen lidstaataansprakelijkheid en directe werking $S$. Prechal, Member State Liability and Direct Effect: What's the Difference After All?, European Business Law Review 2006, afl. 2, p. 299-316.

92. HvJ EG 19 november 1991, gevoegde zaken C-6/90 en C-9/90, ECLI:EU:C:1991:428, Jur. 1991, p. I-05357; NJ 1994/2 (Francovich). Zie voor een bespreking van lidstaataansprakelijkheid de bijdrage van Meijer aan dit nummer en zijn proefschrift: R. Meijer, Staatsaansprakelijkheid wegens schending van Europees gemeenschapsrecht (diss. Groningen), Deventer: Kluwer 2007.

93. HvJ EG 19 november 1991, gevoegde zaken C-6/90 en C-9/90, ECLI:EU:C:1991:428, Jur. 1991, p. I-05357; NJ 1994/2 (Francovich), r.o. 10-27. 


\section{Maandblad \\ Vermogensrecht}

gerekend', dat 'inherent [is] aan het systeem van het Verdrag' ${ }^{94}$ Ook Faccini Dori bleef niet met lege handen achter: zij ontleende aan het Unierecht een recht op schadevergoeding dat zij jegens de Italiaanse staat kon effectueren. ${ }^{95}$ Deze mogelijkheid is echter een last resort: Unierechtelijke lidstaataansprakelijkheid wegens schending van de implementatieverplichting staat pas open indien richtlijnconforme interpretatie van het nationale recht geen uitkomst biedt. ${ }^{96}$

\section{What's next?}

Tegen de achtergrond van de hiervoor (in par. 3.2) beschreven ontwikkelingen rijst de vraag welke rol in de toekomst nog voor richtlijnen zal zijn weggelegd, als het mogelijk is om nationale wetgeving in een geschil tussen particulieren te toetsen aan een algemeen beginsel of EU-Handvestbepaling (indirecte horizontale werking) of zelfs rechtstreeks rechten en verplichtingen kunnen worden ontleend aan een EU-Handvestbepaling (directe horizontale werking). Door sommigen is ook al voor deze ontwikkelingen - betoogd dat het beter zou zijn om richtlijnen wél directe horizontale werking toe te kennen. ${ }^{97}$ Zo ver wil het Hof van Justitie echter niet gaan. Het houdt vaste koers met betrekking tot het 'verbod' op directe horizontale werking. Het argument dat richtlijnen anders niet zouden verschillen van verordeningen, terwijl het VWEU daartussen onderscheidt (art. 288 lid 2 en 3 VWEU), ${ }^{98}$ gaat dus nog steeds op.

De directe horizontale werking van art. 21 lid 1 en art. 31 lid 2 EU-Handvest wekt wel de indruk dat waar deze bepalingen naar de voorgrond komen, de richtlijnen waarin deze bepalingen tot uitdrukking zijn gebracht zelf naar de achtergrond verdwijnen. Waarom zou men in een geschil tussen particulieren immers nog een beroep doen op een richtlijnbepaling, indien men beroep kan doen op een algemeen beginsel of grondrecht van Unierecht dat wél (direct en/of indirect) kan worden ingeroepen? Een mogelijk antwoord op die vraag is dat beroep op een regel van Unierecht - zoals een richtlijnbepaling telkens noodzakelijk is om een beroep te kunnen doen op een algemeen beginsel of grondrecht. In het arrest Kücükdeveci oordeelde het Hof van Justitie dat voor toetsing aan een andere norm dan een aan de orde zijnde richtlijnbepaling - daar: het algemene non-discriminatiebeginsel - vereist was dat die

94. HvJ EG 19 november 1991, gevoegde zaken C-6/90 en C-9/90, ECLI:EU:C:1991:428, Jur. 1991, p. I-05357; NJ 1994/2 (Francovich), r.o. 31 .

95. HvJ EG 14 juli 1994, C-91/92, ECLI:EU:C:1994:292, Jur. 1994 , p. I-3325 e.v.; NJ 1995/321 (Faccini Dori), r.o. 27-30.

96. HvJ EG 14 juli 1994, C-91/92, ECLI:EU:C:1994:292, Jur. 1994 , p. I-3325 e.v.; NJ 1995/321 (Faccini Dori), r.o. 27. Zie over de verhouding tussen lidstaataansprakelijkheid en directe werking S. Prechal, Member State Liability and Direct Effect: What's the Difference After All?, European Business Law Review 2006, afl. 2, p. 299-316.

97. Zie bijv. T. Tridimas, Horizontal effect of directives: a missed opportunity, E.L. Rev. 1994, p. 621-636; P. Craig, Directives: direct effect, indirect effect and the construction of national legislation, E.L. Rev. 1997, p. 519-538; P. Craig, The legal effect of Directives: policy, rules and exceptions, E.L. Rev. 2009, afl. 3, p. 349-377. Zie ook Prechal 2005, p. 255-260, met verdere verwijzingen.

98. Faccini Dori (C-91/92), r.o. 24. richtlijnbepaling die andere norm 'concretiseert'. 99 En in Dansk Industri luidde de formulering dat het algemene nondiscriminatiebeginsel wegens leeftijd enkel van toepassing is op situaties die binnen de werkingssfeer van Richtlijn 2000/78/EG vallen. ${ }^{100}$ Ook voor grondrechten geldt een dergelijke beperking: het EU-Handvest is alleen van toepassing op geschillen die door het Unierecht worden beheerst (art. 51 lid 1 EU-Handvest). ${ }^{101}$ Daarvan is sprake indien een richtlijn in het geding is. Het Hof van Justitie knoopt inmiddels ook aan bij art. 51 lid 1 EU-Handvest voor de vraag of een algemeen beginsel kan worden ingeroepen. ${ }^{102}$ In beide gevallen moet het dus gaan om een situatie die door het Unierecht wordt beheerst, waarbij een richtlijn kan meebrengen dat daarvan sprake is.

Tegen deze achtergrond is het de vraag hoe de overweging van het Hof van Justitie in Bauer en Broßonn moet worden begrepen dat art. 21 lid 1 EU-Handvest kon worden ingeroepen 'zonder dat artikel 51, lid 1, van het Handvest hieraan in de weg staat'. ${ }^{103}$ Eén mogelijke interpretatie is dat het Hof van Justitie hiermee heeft willen uitdrukken dat niet langer hoeft te zijn voldaan aan het vereiste van art. 51 lid 1 EU-Handvest. ${ }^{104}$ Dat zou vergaande gevolgen hebben en indruisen tegen de tekst van het EU-Handvest. Voor richtlijnen zou dit namelijk meebrengen dat zij overbodig zijn voor zover zij normen bevatten die ook in art. 21 lid 1 of art. 31 lid 2 EU-Handvest zijn neergelegd. Ook is denkbaar dat deze zinsnede niets nieuws onder de zon is, en dat het vereiste van art. 51 lid 1 EU-Handvest nog altijd 'gewoon' geldt. ${ }^{105}$ Zo kan men deze zinsnede ook zo lezen dat dit vereiste in het desbetreffende arrest niet aan de toepasselijkheid van het EU-Handvest in de weg stond, omdat er - net als in Cresco - zonder twijfel een Unierechtelijke richtlijn in het geding is. Een andere redenering tot deze uitkomst is dat het Hof met zijn overweging tot uitdrukking brengt dat het feit dat het EU-Handvest is gericht 'tot de lidstaten, uitsluitend wanneer zij het recht van de Unie ten uitvoer brengen' (art. 51 lid 1) niet belet dat zij ook voor particulieren rechten en verplichtingen in het leven kan roepen. ${ }^{106}$ Ik sluit mij aan bij deze opvatting, die steun vindt in de verwijzing in Egenberger naar de arresten waarin het Hof van Justitie oordeelde dat het feit dat non-discriminatie- of vrijverkeerbepalingen uit het verdrag tot de lidstaten zijn gericht er niet aan in de weg staat dat zij in een geschil tussen

99. Kücükdeveci (C-555/07), r.o. 21 en 50. Vgl. Sieburgh 2015, p. 10, die juist betoogt dat het Hof van Justitie dit vereiste in het arrest $A M S$ loslaat.

100. Dansk Industri (C-441/14), r.o. 24 .

101. Vgl. HvJ EU 26 februari 2013, C-617/10, ECLI:EU:C:2013:105, n.g. (Akerberg Fransson), r.o. 19; Association de médiation sociale (AMS) (C-176/12), r.o. 42.

102. HvJ EU 9 maart 2017, C-406/15, ECLI:EU:C:2017:198, n.g. (Milkova), r.o. 50-54. Zie De Mol 2019, p. 377, voetnoot 32.

103. Bauer en Broßonn (gevoegde zaken C-569/16 en 570/16), r.o. 85.

104. In die richting De Mol 2019, p. 381-382. Zij wijst erop dat het Hof van Justitie in Cresco met geen woord rept van art. 51 lid 1 EU-Handvest.

105. Zie Hartkamp 2019, p. 224.

106. Zie de nog te verschijnen dissertatie van I.V. Aronstein, Remedies for Infringements of European Union Law in Legal Relationships between Private Parties (diss. Nijmegen), nog te verschijnen, par. 2.2 en 8.5.2. 
particulieren kunnen worden ingeroepen (directe horizontale werking). ${ }^{107}$ Ook in de toekomst zullen richtlijnen dus van belang blijven, zowel als 'trigger' voor toepasselijkheid van het Unierecht als ter concretisering van normen die in andere Unierechtelijke rechtsbronnen zijn vervat.

Kijken wij vooruit, dan kan in de eerste plaats worden gewezen op Richtlijn (EU) 2019/770 (inzake overeenkomsten voor de levering van digitale diensten of digitale inhoud), die begin dit jaar van kracht is geworden. ${ }^{108}$ Deze richtlijn verplicht de lidstaten om per 1 juli 2021 te voorzien in - kort gezegd - regels over conformiteit van digitale inhoud of dienst, de remedies in geval van een conformiteitsgebrek of leveringsverzuim en de gevolgen van een wijziging van de digitale inhoud of dienst. Voor het Nederlandse privaatrecht zijn onder meer wijzigingen nodig wat betreft de ontbindingsmogelijkheden bij dergelijke overeenkomsten. ${ }^{109}$

Daarnaast wordt op Europees niveau gewerkt aan een collectieve actie. De tekst van een richtlijn die de lidstaten verplicht de mogelijkheid te bieden om consumentenvorderingen in een collectieve actie te kunnen instellen, is begin dit jaar door het Europees Parlement vastgesteld. ${ }^{110}$ Instemming van de Raad ontbreekt vooralsnog. Hoewel het de vraag is wat de mogelijkheid tot het collectief instellen van consumentenvorderingen voor het Nederlandse recht aan veranderingen meebrengt, ${ }^{111}$ zijn er ongetwijfeld jurisdicties waarin deze mogelijkheid - in ieder geval in theorie - een verbetering vormt van de mogelijkheden voor consumenten om hun door het Unierecht toegekende (consumenten)rechten af te dwingen.

\section{Slotsom}

Wat betekent het voorgaande voor het al dan niet karakteriseren van richtlijnen als gamechanger in het Nederlandse en Unie(privaat)recht? In deze bijdrage heb ik stilgestaan bij enkele wijzen waarop richtlijnen hun invloed op het privaatrecht doen gelden anders dan door implementatie in het nationale recht, zoals ambtshalve toetsing of reflexwerking. Voor het Nederlandse privaatrecht geldt dat die invloed soms verder reikt dan het Unierecht voorschrijft, omdat de Nederlandse wetgever of rechter ervoor kiest om verder te gaan dan waartoe

107. I.V. Aronstein, Remedies for Infringements of European Union Law in Legal Relationships between Private Parties (diss. Nijmegen), nog te verschijnen, par. 2.2. Zie Egenberger (C-414/16), r.o. 77, en de daar aangehaalde rechtspraak.

108. Richtlijn (EU) 2019/770 van het Europees Parlement en de Raad van 20 mei 2019 betreffende bepaalde aspecten van overeenkomsten voor de levering van digitale inhoud en digitale diensten (Pb.EU 2019, L 136/1).

109. Zie hierover C. Spierings, Het nieuwe goud: betalen met data, MvV 2019, afl. 6, p. 209-210.

110. Zie www.europarl.europa.eu/doceo/document/TA-8-2019-0222 EN.pdf?redirect (laatstelijk geraadpleegd op 19 juli 2019).

111. Nederland kent met art. 3:305a BW al een collectieve actiemogelijkheid, en op 19 maart 2019 is de wet aangenomen die het mogelijk maakt om in een collectieve actie ook schadevergoeding in geld te vorderen (de Wet afwikkeling massaschade in een collectieve actie, 'WAMCA'). Zie R.R.R. Hardy, Het voorstel voor een richtlijn betreffende representatieve vorderingen ter bescherming van de collectieve belangen van consumenten, WPNR 2018, afl. 7205, p. 637. het Unierecht verplicht. De invloed die richtlijnen uitoefenen op het privaatrecht is vooral groot waar het consumentenbescherming betreft. Dat verbaast niet echt, omdat op dat vlak de meeste richtlijnen voor zijn uitgevaardigd. Ten aanzien van de consumentenbescherming kan men mijns inziens zonder meer spreken van een als gevolg van de doorwerking van richtlijnen veranderd speelveld. Voor de ontwikkeling van Unie(privaat)recht zijn richtlijnen van groot belang omdat juist het ontbreken van directe werking sterk heeft bijgedragen aan de ontwikkeling van verschillende Unierechtelijke remedies. De verplichting tot richtlijnconforme interpretatie, de toetsing van nationale wetgeving aan algemene beginselen van Unierecht of grondrechten uit het EU-Handvest, als ook directe verticale werking én lidstaataansprakelijkheid komen deels voort uit het (in beginsel) ontbreken van directe werking van richtlijnen. Richtlijnen van Unierecht kunnen daarmee wat het Unieprivaatrecht betreft mijns inziens met recht als gamechanger(s) worden aangemerkt. 